\title{
Imre Kertész e o desterro humano
}

Paulo Schiller ${ }^{1}$

Vocês convidaram um tradutor e ganharam de contrabando um psicanalista. Obrigado pelo convite.

Esse evento de hoje ressalta, cada vez mais, a importância de se trabalhar a literatura de testemunho. Trata-se de uma literatura cujos representantes escasseiam, pois existem cada vez menos pessoas vivas daquele período. Esses escritores nos deixaram sua obra para que não fossem esquecidos e para que jamais deixássemos de elaborar novas reflexões a partir delas.

Algumas palavras sobre Miklós Radnóti, o poeta que Sarolta Kobori acaba de citar: nas últimas semanas de sua vida, ele tinha certeza de que iria morrer. Ele é dono de uma literatura de testemunho muito particular pois foi escrita durante o holocausto e não depois dele. Sua grande angústia era não saber se seus poemas seriam encontrados depois, coisa que de fato aconteceu em 1946 quando a vala coletiva em que fora enterrado foi aberta. Exumaram-se os cadáveres e no bolso de seu casaco estavam seus últimos versos. Traduzi alguns deles, que saíram na Ilustríssima no ano passado. Aqui, o verso de Radnóti que trazia a última data.
Desabei a seu lado, seu corpo se virou
e já estava teso, como corda ${ }^{2}$, quando se rompe.
Tiro na nuca. Assim será também o seu fim, sussurrei para mim mesmo, continue deitado sereno.
A paciência agora desabrocha em morte.

1 Psicanalista e tradutor de Imre Kertész, além de Sándor Márai e outros autores húngaros.

2 O companheiro morto era um violinista. 
Der springt noch auf, ouvi acima de mim.

No meu ouvido secava sangue misturado a lama.

Radnóti Miklós, Szentkirályszabadja, 31 de outubro de 1944

A literatura de testemunho sempre abrange os aspectos filosóficos, políticos e sociais, éticos, do desterro. Por que não pensá-los também a partir da clínica psicanalítica? Esse é o trabalho de José Alberto Cotta e de Gilberto Safra, organizadores do livro que está sendo lançado hoje. Vale ressaltar também, e aqui vai uma palavrinha do psicanalista, que a problemática do holocausto aparece no consultório, entre os filhos dos sobreviventes e aparece também, eu já tive a mesma experiência, entre os filhos e netos dos perpetradores. Essa conta não fecha! O que acaba não sendo elaborado pelos pais e pelos avôs, fica como enigma para a descendência.

Algumas palavras sobre a tradução propriamente dita de Sem Destino, de Imre Kertész. Em húngaro o título é Sorstalanság cuja tradução literal seria "ausência de destino", que eu teria gostado que fosse o título do livro em português. Acabou sendo Sem Destino por uma estratégia de vendas do editor. Mas "sem destino" sempre me remete a um motociclista na Rota 66. Ausência de destino teria sido mais interessante.

Tão logo descobri que iria traduzir o Kertész - assim que ele ganhou o Nobel, dois editores me ligaram, pois houve um leilão em Frankfurt durante a feira de livros e um deles acabou comprando os direitos do Sem Destino -, verifiquei que já existia um livro dele publicado no Brasil, antes dele ganhar o Nobel, que era o Kadish, por uma criança não nascida, traduzido do alemão, não do húngaro. Li o livro às pressas e fiquei muito preocupado com o estilo, porque embora Kadish fosse um romance, ele era extremamente complexo do ponto de vista filosófico e da linguagem. Pensei "nossa, vou ter muito trabalho". Depois descobri que o meu maior trabalho seria outro. A dificuldade de tradução do Sem Destino foi na verdade a linguagem, desta vez deliberadamente simples. Tratava-se da narrativa de um adolescente. Portanto, a dificuldade da tradução foi a mesma que a gente encontra nos diálogos: a busca do equilíbrio entre o coloquial e o vulgar.

Kertész escreveu vários gêneros de texto, ficção e não ficção. Nessa discussão de como se falar do holocausto, Kertész sempre defendeu que "só era possivel falar do holocausto por meio da fiç̧ão" e não pela tentativa de documentá-lo,

3 A expressão em alemão significa algo como "ele ainda se debate". 
via realidade. Li recentemente uma fala do Xavier Cercas que diz que "a não fição mata a realidade e a fição a faz, renascer". Curiosamente, Sem Destino é uma ficção claramente autobiográfica.

Com relação ao Kertész, também houve uma polêmica com relação ao prêmio. Fora da Alemanha ninguém o conhecia. Alguns de seus livros haviam sido publicados em inglês antes do Nobel, mas as versões eram ruins, tanto assim que depois da premiação eles foram novamente traduzidos. A outra polêmica que cercou a escolha de Kertész foi sua motivação: teria ela sido política, sem que ele fosse um escritor de alta literatura?

Revendo um pouco a história do Nobel, temos isso desde sempre. Eu diria que existem três tipos de premiação: escritores de ficção, em que a trama e o artesanato das palavras são fundamentais, como por exemplo em Thomas Mann, Saramago, Le Clézio e Faulkner. Entre eles há também escritores que com o tempo se tornaram menores, como Anatole France e Herman Hesse. Houve escritores que não tinham nenhum refinamento em termos de elegância da língua, eram apenas políticos, como por exemplo Winston Churchill. Raramente pensamos nisso. E também existe o gênero em que Kertész trabalha, e que mescla, de certa forma, ficção e não ficção: são seus representantes Elias Canetti, Orhan Pamuk e a vencedora desse ano, Svetlana Alexievich. Aliás tive o prazer de conhecê-la antes de ela ganhar o Nobel. Na verdade, ela faz uma narrativa mista, entre ficção e não ficção, e vale dizer que ela é, certamente, extraordinária. Também poderia usar a expressão "romance sem ficção", que marca bem o trabalho do Kertész. Traduzi outros dois livros dele, um claramente ficcional, com referências ao holocausto seu tema permanente - e um outro de ensaios, A língua exilada.

Algumas palavras sobre literatura de testemunho. Dizia Adorno, em uma de suas frases famosas, que "não se pode escrever poesia depois de Auschwitž". Ele mesmo explica o que a frase significa. Como se poderia representar algo extremo como o holocausto por meio da linguagem, por meio da literatura, sem que se valide ao mesmo tempo, com essa mesma linguagem, a cultura que o produziu, que produziu o holocausto? Giorgio Agamben, o filósofo contemporâneo italiano, por outro lado, diz que o testemunho do holocausto é impossível, por duas razões: por um lado, aqueles que passaram por todo o processo não estão vivos, não têm o que testemunhar; e, por outro lado, as outras testemunhas possíveis são aqueles seres dos campos de concentração que eram chamados de "muçulmanos". Quem eram esses muçulmanos? Tratava-se um jargão dos campos, era o termo que se usava para os mortos vivos. Seres imbecilizados. Eles sofriam da doença da desnutrição, de disenteria, e passavam o dia na posição de reza dos muçulmanos, completamente 
imóveis. De longe, davam a impressão de que eles não tinham mais capacidade de ver nada, de notar nada, de perceber nada. Portanto, quem não via não podia testemunhar.

Voltemos para a discussão lançada pelo Kertész: se a literatura de testemunho caberia, ou não, na forma ficcional. Em seu livro de ensaios ele diz que o modo exemplar de se falar do holocausto seria o de Roberto Benigni, o cineasta italiano, que produziu $A$ Vida é Bela. Na verdade, o filme é quase uma paródia.

Radnóti, o poeta de quem falei há pouco, escolheu a poesia, justamente a partir de um ponto de vista húngaro. Ele se apega a uma visão mítica tradicional entre os poetas húngaros, na literatura húngara clássica, de que o poeta, profético e corajoso, vai provocar, com a sua canção, a emergência inevitável da verdade. Além de tudo, escreve na situação - ele provavelmente escreveu até o último dia de sua vida - em que prevê o próprio fim. Seu último poema, que traduzi, antecede talvez em horas a sua morte. Ele escreve em hexâmetros perfeitos, que é exatamente a forma tradicional da poesia húngara. Vale lembrar que Radnóti, em 1943, se converteu - aparentemente por convicção - ao catolicismo. Mas isso não evitou nem a deportação, nem, depois, a marcha forçada. Na verdade, ele foi assassinado na Hungria, perto da cidade de Győr, depois de ter sido recusada a sua internação no hospital da cidade. Radnóti conseguiu, em meio à fome, ao frio, em meio à certeza da morte, falar em um momento de libertação - importante para nós psicanalistas -, na hora do sono, quando ele conseguia sonhar, e a presença do sonho falava ainda da presença do inconsciente. Por meio da presença do inconsciente é que ainda se podia dizer que ali havia um sujeito, apesar de toda situação de desterro.

Algumas palavras agora desse psicanalista que veio de fato de contrabando. O José Alberto Cotta fala do outro. E eu penso que temos diferentes outros. Temos um outro do espelho, e eu acho que é desse outro que Cotta fala. O outro que nos constitui, e que reconhece em seu olhar que somos humanos também, filhos da linguagem. Fazia parte do processo de extermínio nazista transformar aqueles seres em animais, para que os próprios SS, ou os soldados, se convencessem de que, de fato, os judeus eram animais. "Viu? São animais. Então cabe exterminá-los". Os judeus sabiam que não morreriam como judeus. Assim, na ausência do olhar que nos garante essa identidade, caímos no que Blanchot chama de "a experiência do anonimato", que é com o que você, Cotta, trabalha. Desenraizamento, exílio, dispersão, despedaçamento. Mas a gente também tem o Outro do Lacan, com que eu me identifico um pouco mais. Lacan vai dizer que o inconsciente é o Outro. 
Voltando a mencionar o que para mim é muito importante: na clínica da descendência dos sobreviventes, eles são marcados não pelo desterro, mas pelo que se impõe a partir do indizível, que tem o mesmo efeito que os segredos, que acaba impondo uma repetição. Também na clínica, da mesma forma, o passado, como uma maldição, marca a existência dos filhos e netos dos perpetradores. Como um fantasma que os persegue o tempo todo. Eu vi isso na clínica, mais de uma vez. Embora o genocídio fosse uma política de Estado, sancionada por leis, cada sujeito sabe quando transgride. Porque ele transgride uma lei tácita. Uma lei que não é do Estado, uma lei que não é dos ditadores. E nisso eu lembro a fala de São Paulo, na epístola aos Coríntios, quando ele diz que "existe a transgressão porque existe a leỉ. E aí ele não está falando da lei política, da lei daquele momento histórico. A gente sabe que os SS, nos campos, viviam alcoolizados ou drogados, pois de outra forma seriam incapazes de fazer o que faziam. Ou seja, como mencionei no início, estamos diante de uma conta que não fecha. Não se paga.

No meu entender, o grande desterrado da clínica é o psicótico, esse ser sem identidade que busca, movido por extrema angústia, um nome, uma pátria onde ele possa fincar raízes.

Quanto ao Kertész, para finalizar, eu tinha lido bastante sobre o holocausto antes de traduzir o Sem Destino. Uma das coisas que mais me marcou, que mais me tocou durante a tradução, na leitura do Kertész, foi o final, a volta do sobrevivente à sua pátria de origem. $\mathrm{O}$ modo como ele foi recebido, ou mal recebido. Muitas vezes a decepção de quem o acolhia, surpreso por ele ter continuado vivo. Quando Imre Kertész (e os outros que conseguiram sobreviver aos campos de concentração e às marchas forçadas) voltou pra casa, depois de Auschwitz, não só o povo não acreditava que ele tivesse sobrevivido, mas os que haviam ficado se lamentavam de quanto eles mesmos tinham sofrido, já que na época ninguém suspeitava do que havia de fato ocorrido nos campos de concentração. Acho que aí sim Kertész faz uma alegoria, de que a coisa toda continua até o presente, como vimos depois no Camboja, em Ruanda, na Iugoslávia, enfim, nas minorias que o Estado Islâmico hoje em dia continua dizimando.

Por isso, Cotta e Gilberto Safra, eu acho que vocês devem continuar. O trabalho que vocês fazem, elaborando o que esses sobreviventes testemunharam e desejaram que continuasse vivo sempre. E como diz Kafka, "sempre que a gente escreve a gente sai da fileira dos assassinos". 